\title{
VACTERL/VATER association
}

INSERM

\section{Source}

INSERM. (1999). Orphanet: an online rare disease and orphan drug data base.

VACTERLIVATER association. ORPHA:887

VACT ERL/VATER is an association of congenital malformations typically characterized by the presence of at least three of the following: vertebral defects, anal atresia, cardiac defects, tracheo-esophageal fistula, renal anomalies, and limb abnormalities. 